\title{
ANALISIS REFLEKSI DAN TRANSMISI GELOMBANG PADA PEMECAH GELOMBANG TIANG PANCANG
}

\section{WAVE REFLECTION AND TRANSMISION ANALYSIS OF PILE BREAKWATER}

\author{
Hendra Achiari $^{1 *}$, Ayu Libiaty Ahmad ${ }^{2}$, \& Dede M Sulaiman ${ }^{3}$ \\ ${ }^{1}$ Program Studi Teknik Kelautan, FTSL-ITB, Bandung, 40132, Indonesia \\ ${ }^{2}$ Program Studi Teknik Kelautan, JTIK-ITERA, Lampung Selatan, 35365, Indonesia \\ ${ }^{3}$ Balai Hidraulika dan Geoteknik Keairan, Direktorat Bina Teknik Sumber Daya Air, \\ Kemen PUPR, Bali, 81155, Indonesia \\ *E-mail: achiarihendra@gmail.com
}

\begin{abstract}
The muddy beach vulnerable to wave damage, coastal protection is needed by using permeable breakwaters type. Permeable breakwaters are being developed, namely with Pile Breakwater. The material used for the protoype in laboratory is rounded insulated bamboo, which is round bamboo from Pringgodani garden with a diameter of $1 \mathrm{~cm}$, height of $20 \mathrm{~cm}$ with a multiblock wooden bulkhead with thick of $2 \mathrm{~cm}$. Reflection and transmission analysis on the results of $2 D$ physical modelling of the breakwater is needed to achieve optimization in its use. Breakwater is effective in scenarios that have smaller $K_{t}$ values and larger $K_{r}$ values. In this study the test was carried out with water level at Mean Sea Level (MSL) $44 \mathrm{~cm})$ and High Water Level $(H W L)(50 \mathrm{~cm})$ with 2 spatial scenarios between $1 \mathrm{~cm}$ and $2 \mathrm{~cm}$. Then the calculation results of $K_{t}$ and $K_{r}$ are compared with nondimensional wave steepness variables $\left(H_{i} / g T^{2}\right)$ and wave slope $\left(H_{i} / L\right)$. From this laboratory study, it is shown that $K_{t}$ has lower values at MSL and $K_{r}$ has higher values at MSL. This fact shows that the permeable breakwater with bamboo more effective at low water level than at high water level.
\end{abstract}

Keywords: permeable breakwater, pile breakwater, reflection, transmission

\begin{abstract}
ABSTRAK
Pantai berlumpur rentan terhadap kerusakan akibat gelombang, sehingga diperlukan perlindungan pantai yang salah satunya menggunakan pemecah gelombang tipe permeable. Tipe permeable yang dikembangkan ini disebut sebagai Pemecah Gelombang Tiang Pancang. Bahan yang digunakan untuk memodelkan struktur tersebut (prototipe) di laboratorium adalah bambu bulat bersekat yaitu bambu bulat dari taman Pringgodani dengan diameter $1 \mathrm{~cm}$, tinggi $20 \mathrm{~cm}$ dengan sekat kayu multiblok setebal $2 \mathrm{~cm}$. Analisis refleksi dan transmisi terhadap hasil pengujian model fisik 2D terhadap pemecah gelombang diperlukan untuk mencapai optimasi dalam penggunaannya. Hasil pengujian laboratorium membuktikan bahwa Pemecah Gelombang ini cukup efektif pada skenario yang memiliki nilai $K_{t}$ yang lebih kecil dan nilai $K_{r}$ yang lebih besar. Pada percobaan ini pengujian dilakukan dengan skenario tinggi muka air pada Mean Sea Level (MSL) (44 cm) dan High Water Level (HWL) $(50 \mathrm{~cm})$ dengan 2 skenario spasi antar tiang yaitu $1 \mathrm{~cm}$ dan $2 \mathrm{~cm}$ pada masing-masing tinggi muka air. Kemudian hasil perhitungan $K_{t} K_{t}$ dan $K_{r}$ dibandingkan dengan variabel nondimensional kecuraman gelombang $\left(H_{i} / g T^{2}\right)$ dan kemiringan gelombang $\left(H_{i} / L\right)$. Hasil percobaan laboratorium menunjukkan bahwa nilai $K_{t}$ lebih rendah pada saat kondisi MSL, dan nilai $K_{r}$ lebih tinggi pada saat kondisi MSL hal ini menunjukkan bahwa Pemecah Gelombang Bambu Bulat Bersekat ini lebih efektif pada muka air rendah dari pada muka air tinggi.
\end{abstract}

Kata kunci: pemecah gelombang tiang pancang, permeable breakwater, refleksi, transmisi

\section{PENDAHULUAN}

Pantai merupakan wilayah yang kompleks namun memiliki potensi sumber daya yang besar. Salah satu pantai yang terdapat di Indonesia yaitu jenis pantai berlumpur yang dicirikan oleh ukuran butiran sedimen sangat halus dan memiliki tingkat 
bahan organik yang tinggi serta banyak dipengaruhi oleh pasang surut. Kemiringan pantai ini sangat landai, sehingga air dapat tertahan lebih lama di dalam substrat. Pantai tipe ini relatif mudah berubah bentuk, mengalami deformasi, dan tererosi. Erosi pantai yang terus menerus ini akan menimbulkan masalah yang cukup serius. Secara umum, kerusakan ini disebabkan oleh beberapa faktor hidro-oseanografi. Salah satu faktor hidro-oseanografi yang sangat memengaruhi jenis pantai ini adalah gelombang yang berasal dari lepas pantai.

Gelombang laut dapat menimbulkan energi untuk membentuk pantai, menimbulkan arus dan transport sedimen dalam arah tegak lurus dan sepanjang pantai, serta menyebabkan gaya-gaya yang bekerja pada bangunan pantai (Umar, 2011). Saat melalui bangunan pantai, gelombang tersebut akan dipantulkan (refleksi) dan diteruskan (transmisi). Pembagian besarnya energi gelombang yang dipantulkan dan diteruskan tergantung karakteristik gelombang datang (periode dan tinggi gelombang), tipe bangunan peredam gelombang (permukaan halus dan kasar, lulus air dan tidak lulus air) dan geometrik bangunan peredam (kemiringan, elevasi, dan puncak bangunan).

Perlindungan terhadap pantai berlumpur dibutuhkan untuk mencegah dan mengurangi kerusakan akibat gelombang laut. Salah satu perlindungan pantai yang digunakan untuk pantai berlumpur adalah menggunakan pemecah gelombang tipe permeable atau berpori yang lolos air. Pemecah gelombang tipe permeable ini memiliki struktur bercelah yang terdapat jarak antara satu dan lainnya, sehingga dapat meloloskan sebagian air yang datang akibat gelombang dari lepas pantai.

Tipe permeable breakwater yang sedang dikembangkan sekarang ini adalah pemecah gelombang tiang pancang dari bambu bulat bersekat (Figure 1). Bangunan pelindung pantai ini dipasang sejajar dan tidak menempel di pantai dengan elevasi puncaknya di atas muka air tinggi, berfungsi mereduksi energi gelombang yang lewat dan karena itu mengurangi bahkan mematikan gerakan gelombang di belakang struktur. Struktur pemecah gelombang ini diharapkan bisa membuat transmisi gelombangnya rendah dan refleksi gelombangnya tinggi. Pemecah gelombang ini merupakan struktur yang sangat efektif merehabilitasi pantai yang mengalami erosi dan mampu menambah lebar pantai ke arah laut dengan terbentuknya salient dan tombolo (Sulaiman, 2017).

Bahan yang digunakan untuk pemecah gelombang pada percobaan ini adalah bambu bulat bersekat yaitu bambu bulat dari taman Pringgodani diameter $1 \mathrm{~cm}$, tinggi $20 \mathrm{~cm}$ dengan sekat kayu multiblok setebal $2 \mathrm{~cm}$ (Figure 3). Penggunaan material bambu ini merupakan pengembangan dari penelitian yang telah dilakukan oleh proyek Building with Nature yang menggunakan belukar (brush-wood) yang digunakan untuk pantai berlumpur di Demak, Jawa Tengah. Pemecah gelombang tipe ini dapat membentuk perairan yang lebih tenang dan melindungi pertumbuhan mangrove yang banyak tumbuh pada wilayah pantai berlumpur (Sulaiman \& Larasari, 2017.

Pada makalah ini efektivitas dari pemecah gelombang akan diketahui dengan menghitung $K_{t}$ (Koefisien Transmisi) dan $K_{r}$ (Koefisien Refleksi) dari hasil pengujian model fisik dua dimensi (2D).

\section{METODE PENELITIAN}

\subsection{Bahan}

Model tersusun atas barisan tiang bambu terbuat dari bambu taman Pringgodani berdiameter $1 \mathrm{~cm}$, tinggi $20 \mathrm{~cm}$ yang dipancangkan di atas kayu multiblok berukuran $100 \times 15 \times 2 \mathrm{~cm}$.

\subsection{Model Set-up}

Uji model fisik dilakukan pada saluran gelombang dua dimensi yang mempunyai panjang $45 \mathrm{~m}$, lebar $1 \mathrm{~m}$, dan kedalaman $1 \mathrm{~m}$. Saluran gelombang bermaterial beton dengan dinding kaca di sekitar lokasi penempatan model. Ujung dari kolam ini dilengkapi dengan alat pembentuk 


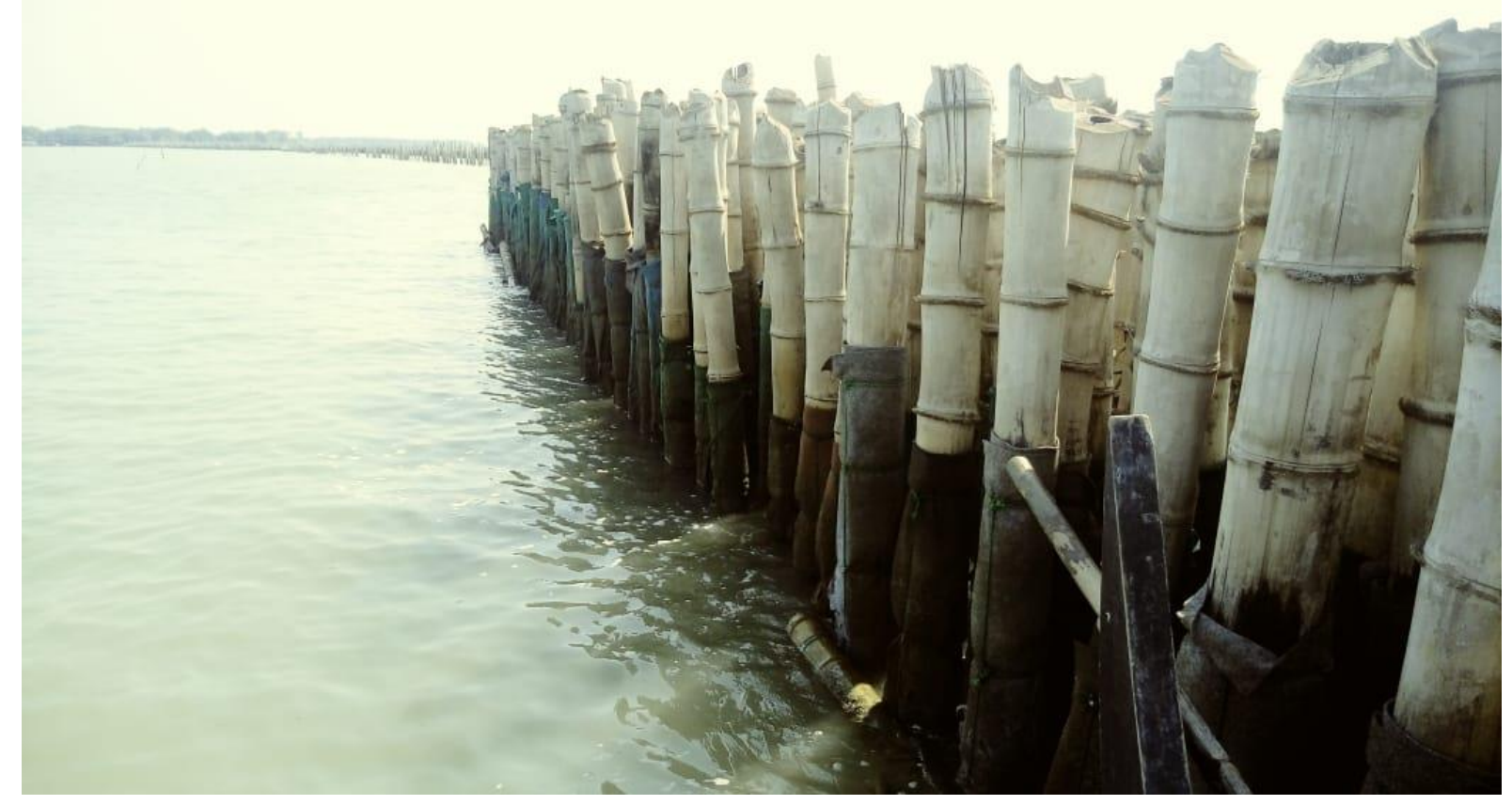

Figure 1. An application example of using a circular bamboo breakwater insulated on a muddy beach (Sulaiman, 2017).

gelombang, ujung satunya terdapat peredam gelombang terbuat dari tumpukan batu. Struktur pemecah gelombang dimodelkan dengan skala $1: 10$, tersusun atas barisan tiang bambu yang dipancangkan di atas kayu multiblok berukuran 100 x $15 \mathrm{~cm}$. Lebar sebesar $15 \mathrm{~cm}$ ini dipilih untuk memodelkan lebar pemecah gelombang ambang rendah (disingkat "Pegar") di lapangan sebesar $1,5 \mathrm{~m}$. Data gelombang dicatat secara otomatis menggunakan seperangkat wave probe pada dua kondisi muka air yaitu: i) pada kondisi HWL (kedalaman di laboratorium sebesar $50 \mathrm{~cm}$, kedalaman di lapangan setinggi $1,7 \mathrm{~m}$ ) dan ii) pada kondisi MSL (kedalaman di laboratorium sebesar $44 \mathrm{~cm}$, mencerminkan di lapangan setinggi 1,1 m). Eksperimen dilakukan dengan melewatkan gelombang melalui pegar tiang pancang kemudian mengukur tinggi gelombang insiden dan transmisi. Set-up percobaan pemecah gelombang untuk kondisi muka air HWL dapat dilihat pada (Figure 2), sedangkan layout-nya dapat dilihat pada Figure 3, dan Figure 4.

Konfigurasi susuan deret bambu bulat bersekat di lapangan ada 2 jenis yaitu disusun berderet lurus sejajar (Figure 4) ataupun disusun berselang seling (tidak sejajar). Pada percobaan kali ini, hanya dipilih susunan sejajar untuk menyimulasi-kan dan menguji efektifitas pelindung ambang rendah tiang pancang seperti yang sudah diaplikasikan pada pantai berlumpur di Demak, Jawa Tengah oleh Sulaiman (2017).

\subsection{Metode}

\subsubsection{Skenario Model}

Skenario pada uji model fisik dapat dilihat pada Table 1. Skenario pada percobaan ini menggunakan kombinasi 2 tinggi gelombang sebesar $6 \mathrm{~cm}$ dan $10 \mathrm{~cm}$, dan kombinasi periode gelombang dengan interval 0,4 detik disesuaikan dengan ketersediaan properties gelombang bangkitan dari wave generator di Laboratorium.

\subsubsection{Memperoleh Tinggi $(H)$ dan Periode $(T)$ Gelombang}

Data gelombang diambil dari WP 01, WP 02 dan WP 03. Data dari WP 01 adalah tinggi gelombang datang $\left(H_{i}\right)$, data WP 02 digunakan untuk menganalisis gelombang refleksi $\left(H_{r}\right)$, sedangkan data WP 03 digunakan untuk gelombang transmisi $\left(H_{t}\right)$. 
Data tinggi gelombang $(H)$ dan periode gelombang $(T)$ menggunakan data yang diperoleh dari wave probe untuk kemudian diproses lebih lanjut dengan metode zero up-crossing.

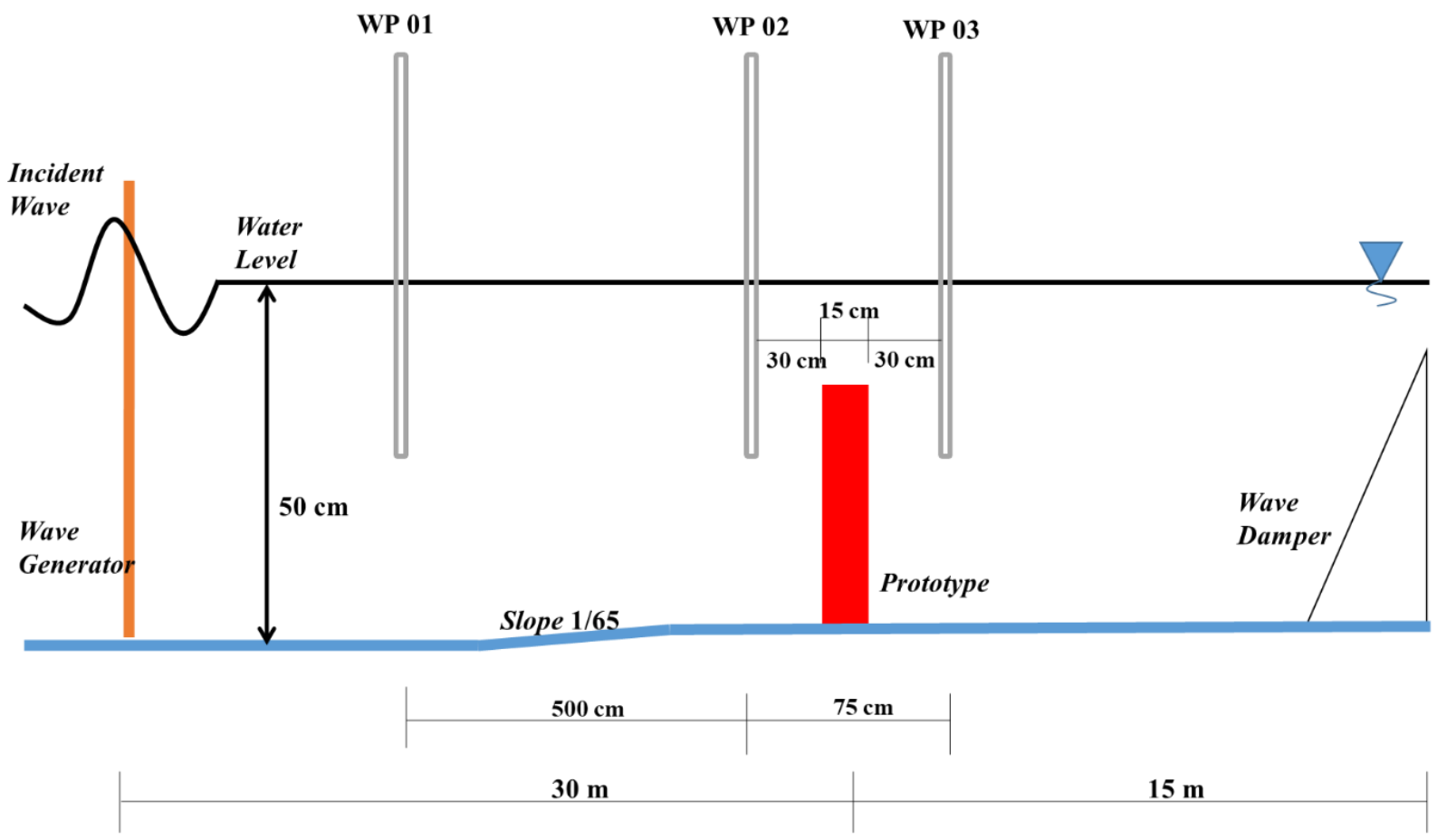

Note: $W P 01=$ Wave probe for incident wave, WP $02=$ Wave probe for reflection wave, and WP 03 = Wave probe for transmission wave.

Figure 2. 2D physical modelling setup at HWL water level conditions.

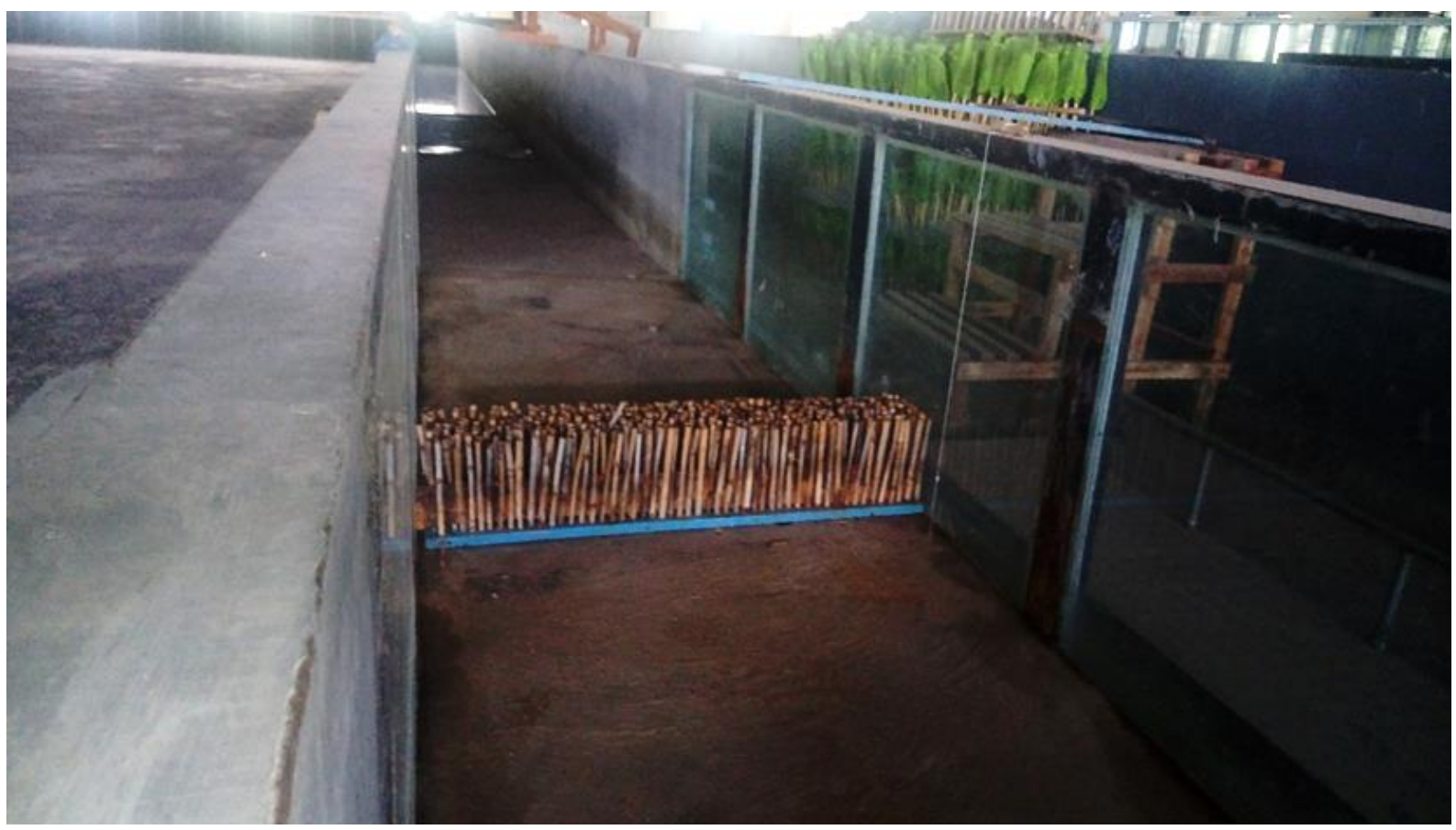

Figure 3. The round bamboo breakwater model is insulated in the wave flume. 


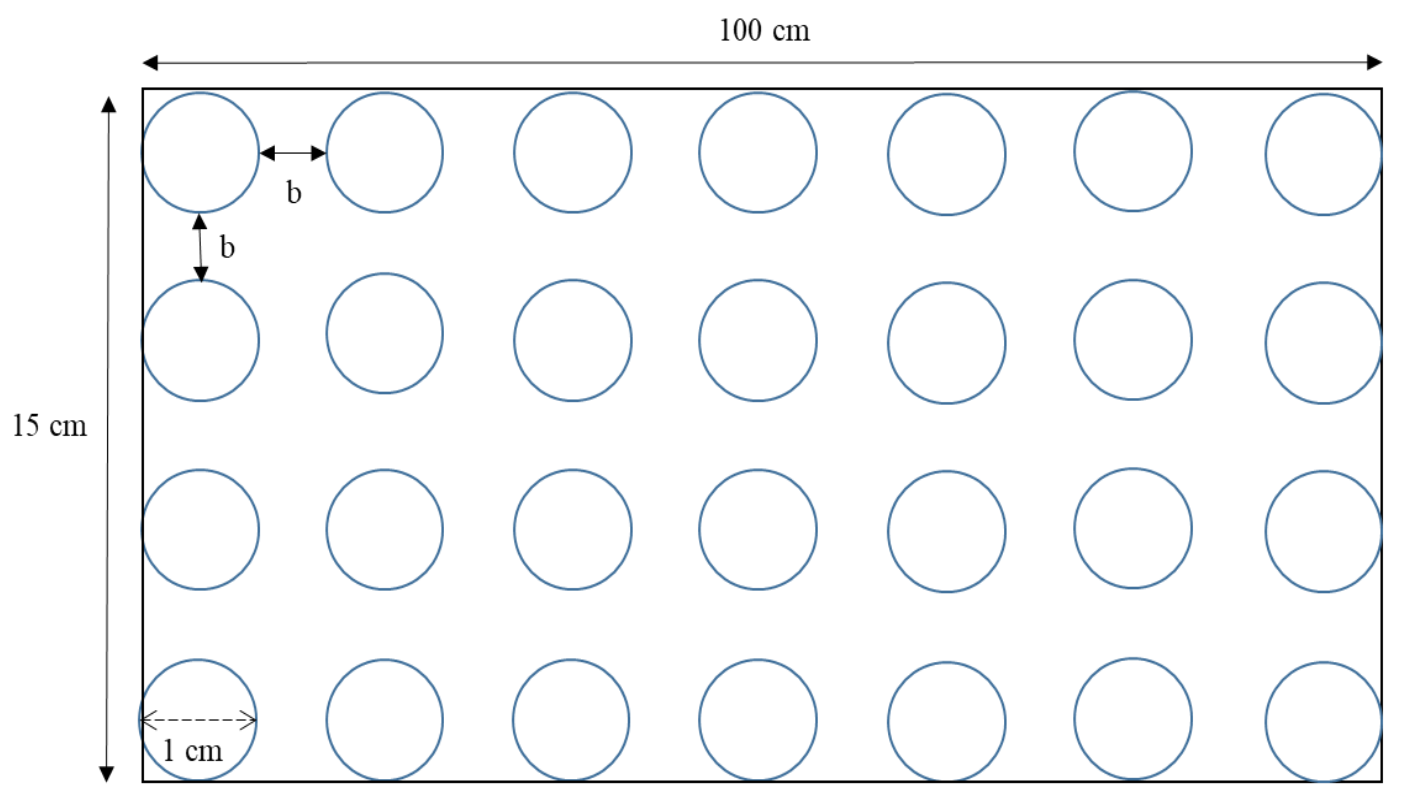

Figure 4. The model of a circular bamboo breakwater with insulation above.

Table 1. Physical Modelling Scenario.

\begin{tabular}{cccc}
\hline Pile Formation & Pile spaces, $b(\mathrm{~cm})$ & Period $(\mathrm{s})$ & Wave Height $(\mathrm{cm})$ \\
\hline Straight & 1 & $1.2,1.6,2.0$ & 6,10 \\
& 2 & $1.2,1.6,2.0$ & 6,10 \\
\hline
\end{tabular}

\subsubsection{Memperoleh Koefisien Transmisi}

Tinggi gelombang transmisi merupakan tinggi gelombang yang diteruskan $H_{t}$ ini diperoleh dari WP 03 yang terletak dibelakang pemecah gelombang pada pemodelan fisik 2D ini. Hasil perekaman WP 03 diidentifikasi menggunakan zero downcrossing. Koefisien transmisi $\left(K_{t}\right)$ adalah rasio antara tinggi gelombang transmisi $\left(H_{t}\right)$ dan tinggi gelombang datang $\left(H_{i}\right)$. Koefisien transmisi dapat dituliskan sebagai berikut:

$K_{t}=\frac{H_{t}}{H_{i}}$

Keterangan: $K_{t}$ adalah koefisien transmisi, $H_{t}$ adalah tinggi gelombang transmisi (m), dan $H_{i}$ adalah tinggi gelombang datang (m).

\subsubsection{Memperoleh Koefisien Refleksi}

Koefisien refleksi $\left(K_{r}\right)$ adalah rasio antara tinggi gelombang refleksi $\left(H_{r}\right)$ dan tinggi gelombang datang $\left(H_{i}\right)$. Koefisien refleksi dapat dituliskan sebagai berikut:

$K_{r}=\frac{H_{r}}{H_{i}}$

$H_{r}=\frac{H_{\operatorname{maks}}-H_{\min }}{2}$

$H_{i}=\frac{H_{\operatorname{maks}}+H_{\min }}{2}$

$K_{r}=\frac{H_{\operatorname{maks}}-H_{\min }}{H_{\operatorname{maks}}+H_{\min }}$

Keterangan: $H_{\text {maks }}$ adalah tinggi gelombang maksimum (m), $H_{\min }$ adalah tinggi gelombang minimum (m), $K_{r}$ adalah koefisien refleksi, dan $H_{r}$ adalah tinggi gelombang refleksi (m).

\subsection{Analisis Dimensional}

Analisis dimensional ini menggunakan Buckingham Method. Hasil penurunan menggunakan metode Buckingham, terhadap variabel-variabel terlibat yaitu: $H_{i}$ 
(tinggi gelombang datang, satuan: $\mathrm{m}$ ), $L$ (Panjang gelombang, satuan: $\mathrm{m}$ ), $T$ (Periode gelombang, satuan: detik), $h$ (kedalaman air, satuan: $\mathrm{m}), b$ (jarak spasi antar tiang, satuan: $\mathrm{m}), \quad g$ (percepatan gravitasi, satuan: $\mathrm{m} /$ $\operatorname{detik}^{2}$, diperoleh relasi bilangan nondimensional sebagai berikut:

$$
\begin{aligned}
& K_{t}=f\left(\frac{H_{i}}{h}, \frac{H_{i}}{L}, \frac{b}{H_{\bar{i}}}, \frac{H_{i}}{g T^{3}}\right) \\
& K_{r}=f\left(\frac{H_{i}}{h}, \frac{H_{i}}{L}, \frac{b}{H_{i}}, \frac{H_{i}}{g T^{2}}\right)
\end{aligned}
$$

\section{HASIL DAN PEMBAHASAN}

\subsection{Pengaruh $H_{i} / L$ dan $H_{i} / g T^{2}$ terhadap Koefisien Transmisi}

Koefisien transmisi $\left(K_{t}\right)$ merupakan besarnya energi gelombang yang diteruskan setelah melewati suatu penghalang (struktur). Berdasarkan hasil pengukuran dan perhitungan, akan dilihat pengaruh kecuraman gelombang baik dalam parameter $\left(H_{i} / L\right)$ maupun dalam parameter $\left(H_{i} / g T^{2}\right)$ terhadap nilai $K_{t}$ pada kondisi MSL dan HWL dengan 2 skenario spasi antar tiang (b), yaitu $b=1 \mathrm{~cm}$ dan $b=2 \mathrm{~cm}$.

Nilai $K_{t}$ sebagai fungsi dari $H_{i} / L$ pada kondisi MSL dengan $b=1 \mathrm{~cm}$ dan $b=2$ $\mathrm{cm}$ ditunjukkan pada grafik Figure 5 dan Figure 6. Grafik tersebut menunjukkan bahwa semakin besar nilai $H_{i} / L$ maka semakin kecil nilai $K_{t}$ nya dan sebaliknya semakin kecil nilai $H_{i} / L$ maka semakin besar nilai $K_{t}$ nya baik pada kedua skenario spasi pada kondisi MSL.

Nilai $K_{t}$ sebagai fungsi dari $H_{i} / L$ pada kondisi HWL dengan $b=1 \mathrm{~cm}$ dan $b=$ $2 \mathrm{~cm}$ ditunjukkan pada grafik Figure 7 dan Figure 8. Grafik tersebut menunjukkan bahwa semakin besar nilai $H_{i} / L$ maka semakin kecil nilai $K_{t}$ nya dan sebaliknya semakin kecil nilai $H_{i} / L$ maka semakin besar nilai $K_{t}$ nya pada kedua skenario spasi pada kondisi HWL.

Nilai $K_{t}$ sebagai fungsi dari $H_{i} / g T^{2}$ pada kondisi MSL dengan $b=1 \mathrm{~cm}$ dan $b=2$ $\mathrm{cm}$ ditunjukkan pada grafik Figure 9 dan Figure 10. Grafik tersebut menunjukkan bahwa semakin besar nilai $H_{i} / g T^{2}$ maka semakin kecil nilai $K_{t}$ nya dan sebaliknya semakin kecil nilai $H_{i} / g T^{2}$ maka semakin besar nilai $K_{t}$ nya pada kedua skenario spasi pada kondisi MSL.

Nilai $K_{t}$ sebagai fungsi dari $H_{i} / g T^{2}$ pada kondisi MSL dengan $b=1 \mathrm{~cm}$ dan $b=2$ $\mathrm{cm}$ ditunjukkan pada grafik Figure 11 dan Figure 12. Grafik tersebut menunjukkan bahwa semakin besar nilai $H_{i} / g T^{2}$ maka semakin kecil nilai $K_{t}$ nya dan sebaliknya semakin kecil nilai $H_{i} / g T^{2}$ maka semakin besar nilai $K_{t}$ nya pada kedua skenario spasi pada kondisi HWL.

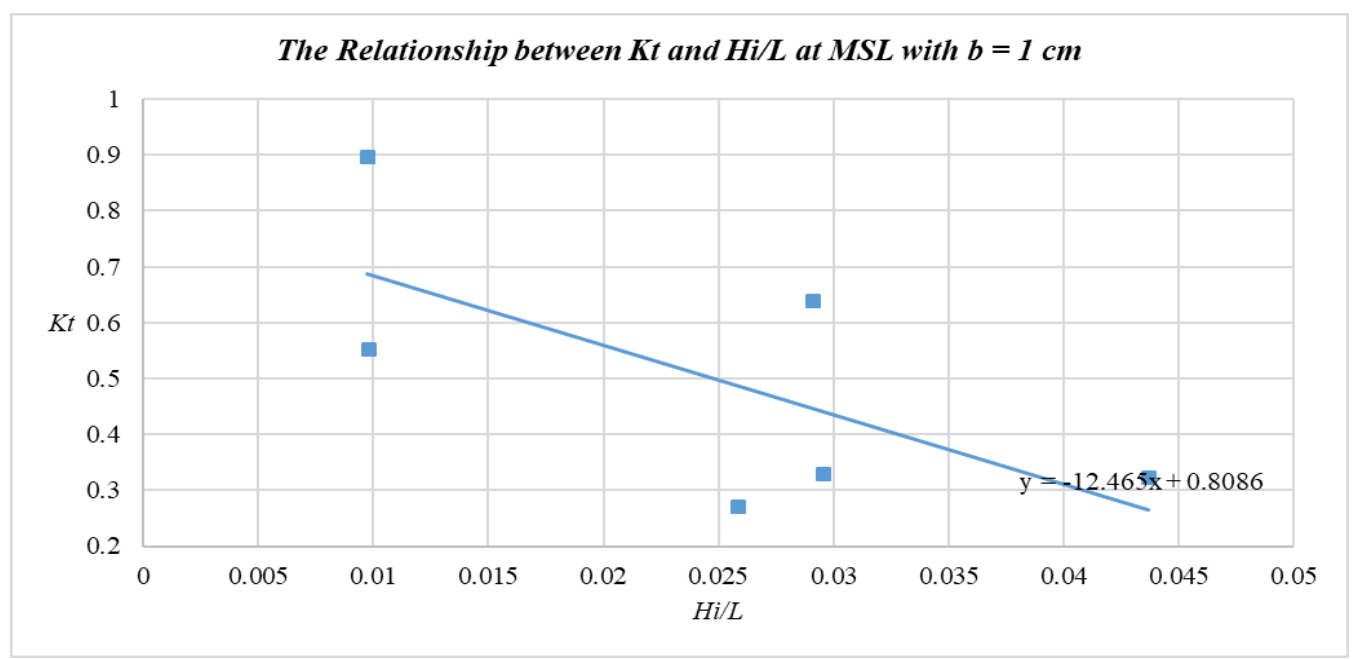

Figure 5. $K_{t}$ vs $H_{i} / L$ for MSL conditions with spaces $1 \mathrm{~cm}$. 


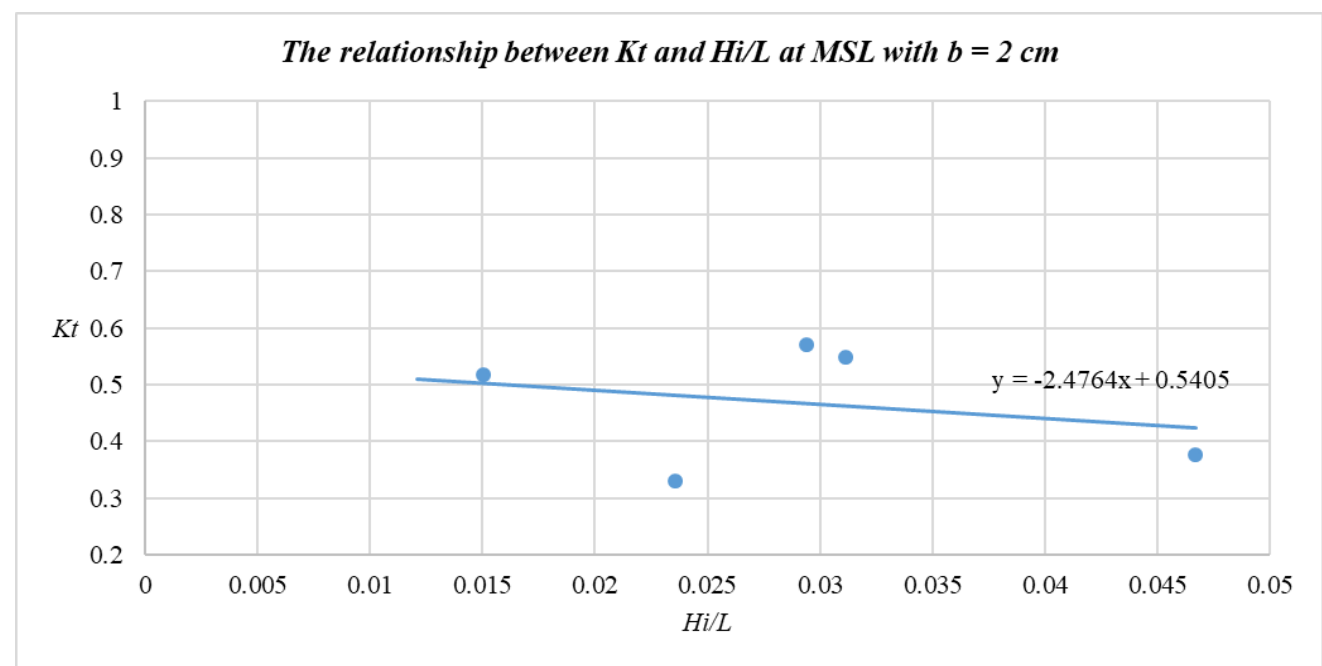

Figure 6. $K_{t}$ vs $H_{i} / L$ for MSL conditions with spaces $2 \mathrm{~cm}$.

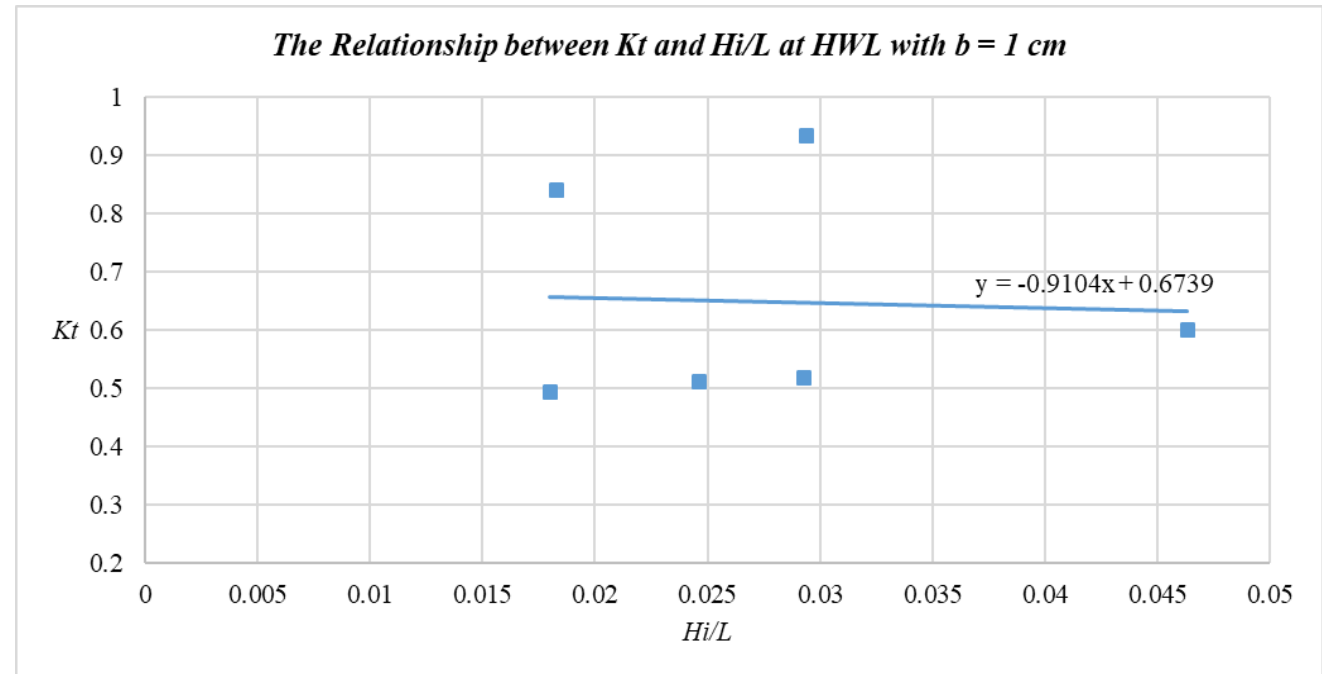

Figure 7. $K_{t}$ vs $H_{i} / L$ for $H W L$ conditions with spaces $1 \mathrm{~cm}$.

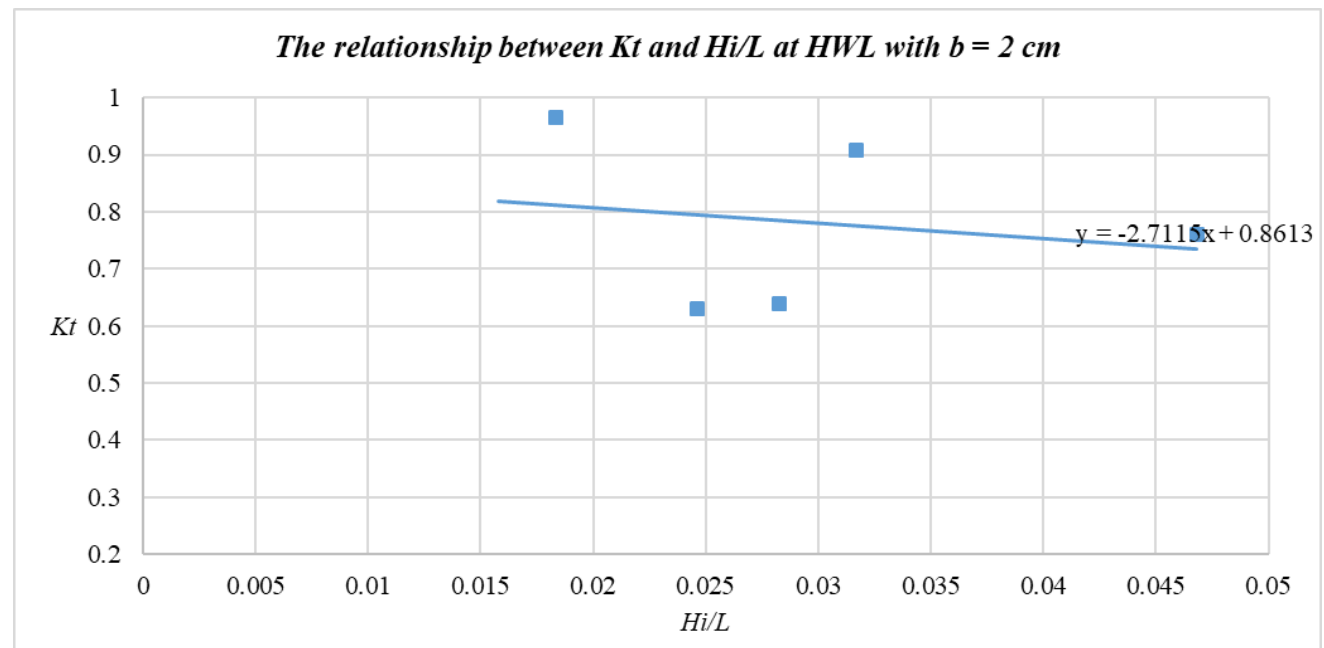

Figure 8. $K_{t}$ vs $H_{i} / L$ for $H W L$ conditions with spaces $2 \mathrm{~cm}$. 
Analisis Refleksi dan Transmisi Gelombang pada Pemecah Gelombang ...

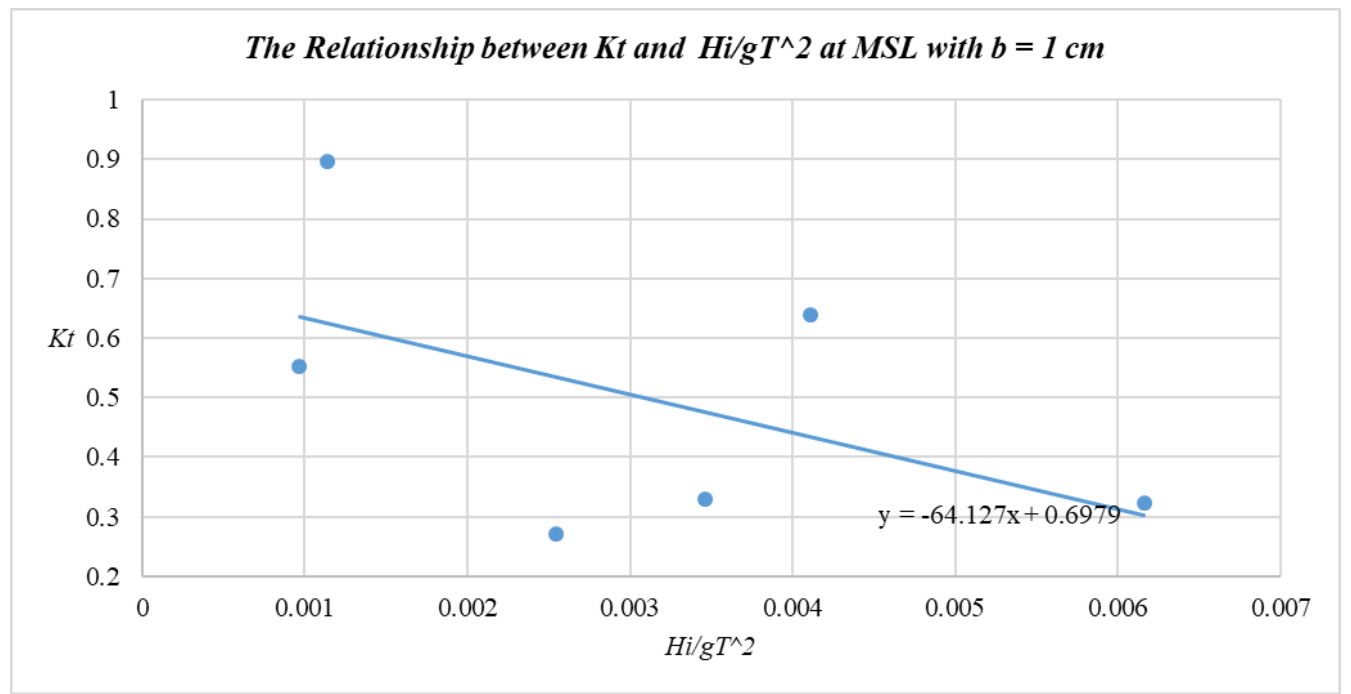

Figure 9. $K_{t}$ vs $H_{i} / g T^{2}$ for MSL conditions with spaces $1 \mathrm{~cm}$.

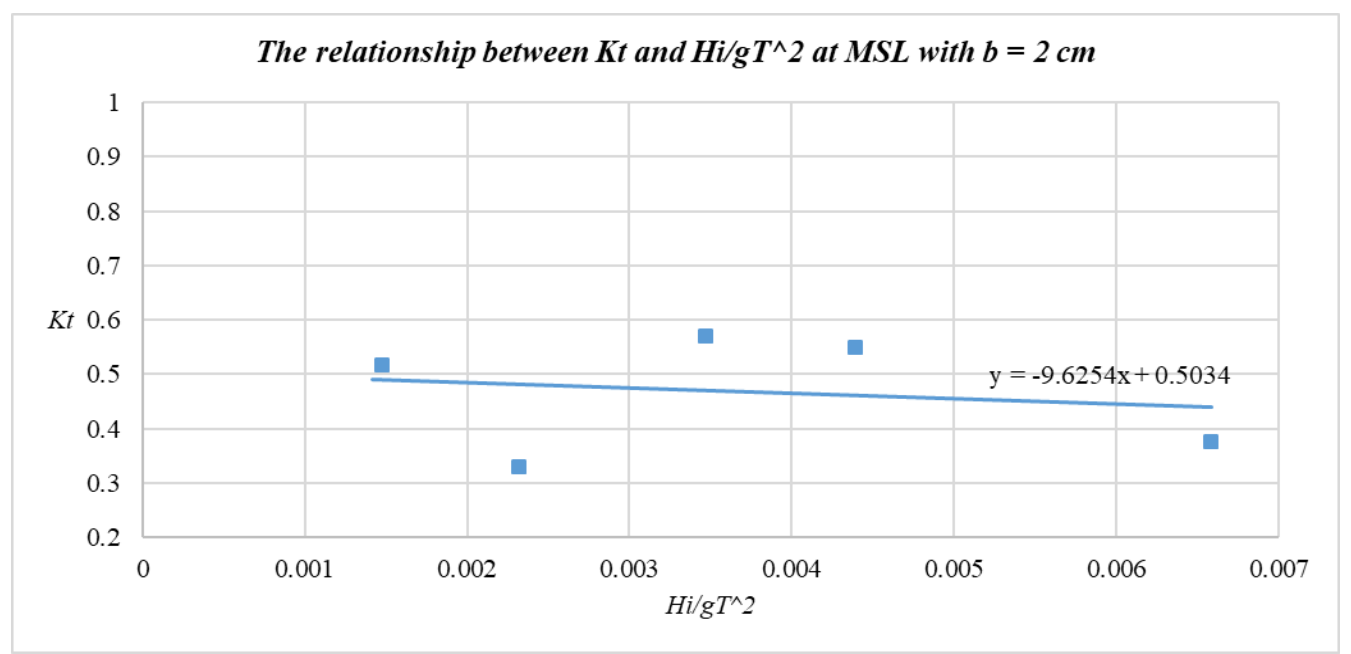

Figure 10. $K_{t}$ vs $H_{i} / g T^{2}$ for MSL conditions with spaces $2 \mathrm{~cm}$.

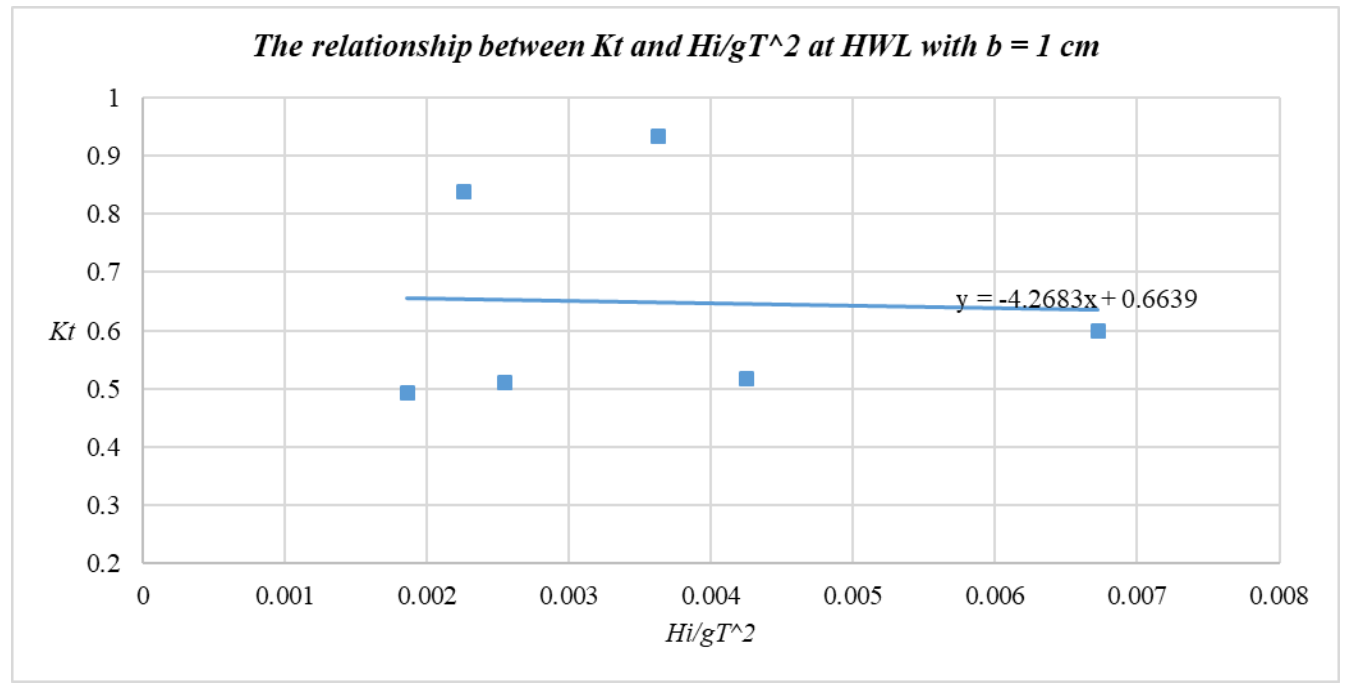

Figure 11. $K_{t}$ vs $H_{i} / g T^{2}$ for $H W L$ conditions with spaces $1 \mathrm{~cm}$. 


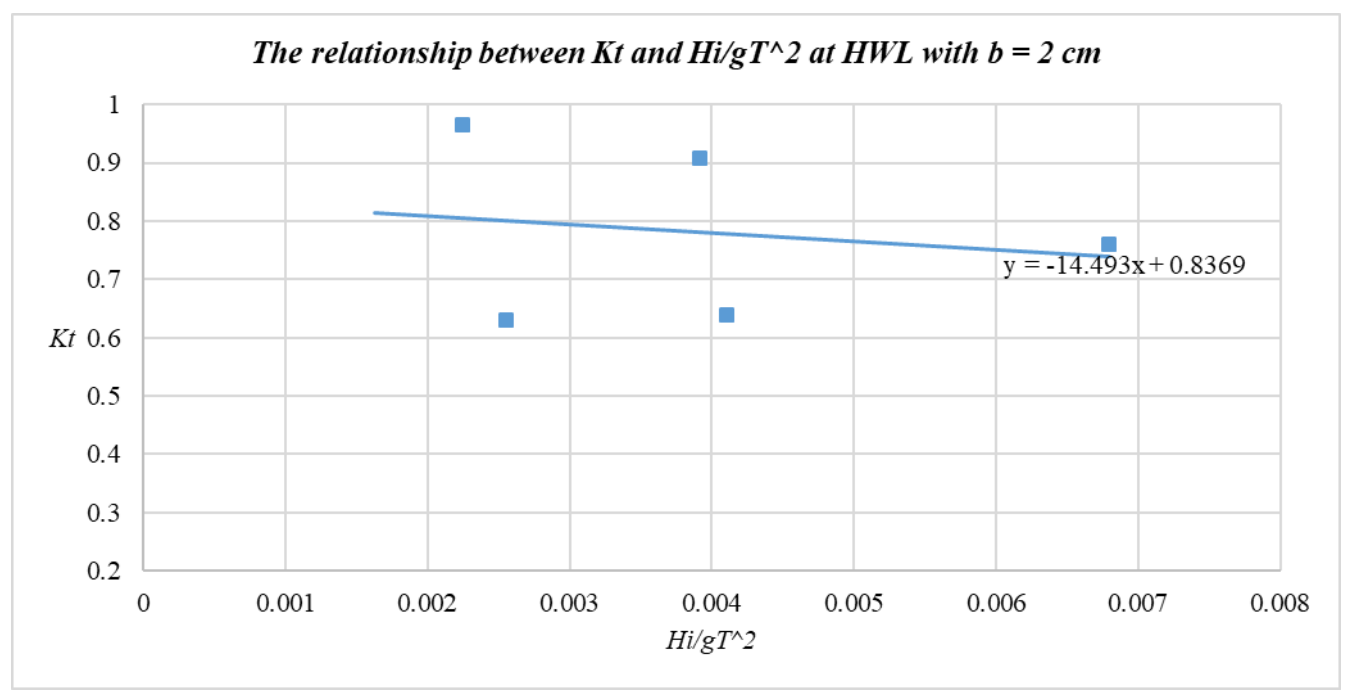

Figure 12. $K_{t}$ vs $H_{i} / g T^{2}$ for $H W L$ conditions with spaces $2 \mathrm{~cm}$.

Hasil pengujian model fisik 2D menggunakan pemecah gelombang bambu bulat bersekat menunjukkan, $K_{t}$ memiliki hubungan yang berbanding terbalik terhadap variabel $H_{i} / L$ dan $H_{i} / g T^{2}$ yang berarti dengan nilai $K_{t}$ bertambah seiring dengan berkurangnya nilai dari kedua variabel yang berarti jika kita menginginkan $K_{t}$ yang kecil maka struktur pemecah gelombang sangat ideal ditempatkan pada perairan yang besar kemiringan gelombangnya.

Hasil tersebut sesuai dengan penelitian yang telah dilakukan sebelumnya oleh Wurjanto et al. (2010), Sulaiman \& Larasari (2017), dan Herbich \& Douglas (1988) bahwa nilai $K_{t}$ bertambah seiring dengan berkurangnya nilai $H_{i} / g T^{2}$. Sesuai dengan penelitian yang telah dilakukan Herbich \& Douglas (1988) bahwa nilai $K_{t}$ bertambah seiring dengan berkurangnya nilai $H_{i} / L$.

Diantara formasi dengan spasi $1 \mathrm{~cm}$ dan model dengan spasi $2 \mathrm{~cm}$ nilai koefisien transmisi lebih tinggi pada model dengan spasi $2 \mathrm{~cm}$. Hal ini menunjukkan bahwa semakin besar spasi antar bambu dari struktur maka nilai $K_{t}$ semakin tinggi dan semakin kecil spasi antar bambu maka semakin kecil nilai $K_{t}$. Hasil ini sesuai dengan penelitian Koftis et al. (2012) yang menyatakan bahwa semakin kecil spasi antar tiang, maka semakin kecil energi yang diteruskan.
Jika dibandingkan antara model dengan kondisi MSL dan HWL, dapat dilihat bahwa nilai $K_{t}$ relatif lebih rendah pada saat kondisi MSL dan lebih besar pada kondisi HWL. Hal ini menunjukkan bahwa pemecah gelombang bambu bulat bersekat ini lebih efisien pada perairan dengan muka air yang lebih rendah. Hasil ini sesuai dengan penelitian Herbich \& Douglas (1988) yang menyatakan bahwa semakin rendah kedalaman perairan nilai $K_{t}$ semakin kecil.

\subsection{Pengaruh $H_{i} / L$ dan $H_{i} / g T^{2}$ terhadap Koefisien Refleksi}

Koefisien refleksi $\left(K_{r}\right)$ merupakan besarnya energi gelombang dipantulkan. Berdasarkan hasil pengukuran dan perhitungan, akan dilihat pengaruh kemiringan gelombang $\left(H_{i} / L\right)$ dan kecuraman gelombang $\left(H_{i} / g T^{2}\right)$ terhadap nilai $K_{r}$ pada kondisi MSL dan HWL dengan 4 skenario spasi antar tiang $(b)$ setiap kondisinya.

Nilai $K_{r}$ sebagai fungsi dari $H_{i} / L$ pada kondisi MSL dengan $b=1 \mathrm{~cm}$ dan $b=2$ cm ditunjukkan pada grafik Figure 13 dan Figure 14. Grafik tersebut menunjukkan bahwa semakin besar nilai $H_{i} / L$ maka semakin besar pula nilai $K_{r}$ nya dan sebaliknya semakin kecil nilai $H_{i} / L$ maka semakin kecil pula nilai $K_{r}$ nya baik pada kedua skenario spasi pada kondisi MSL. 
Nilai $K_{r}$ sebagai fungsi dari $H_{i} / L$ pada kondisi HWL dengan $b=1 \mathrm{~cm}$ dan $b=$ $2 \mathrm{~cm}$ ditunjukkan pada grafik Figure 15 dan Figure 16. Grafik tersebut menunjukkan bahwa semakin besar nilai $H_{i} / L$ maka semakin besar pula nilai $K_{r}$ nya dan sebaliknya semakin kecil nilai $H_{i} / L$ maka semakin kecil pula nilai $K_{r}$ nya baik pada kedua skenario spasi pada kondisi HWL.

Nilai $K_{r}$ sebagai fungsi dari $H_{i} / g T^{2}$ pada kondisi MSL dengan $b=1 \mathrm{~cm}$ dan $b=2$ $\mathrm{cm}$ ditunjukkan pada grafik Figure 17 dan Figure 18. Grafik tersebut menunjukkan bahwa semakin besar nilai $H_{i} / g T^{2}$ maka semakin besar pula nilai $K_{r}$ nya dan sebaliknya semakin kecil nilai $H_{i} / g T^{2}$ maka semakin kecil pula nilai $K_{r}$ nya baik pada kedua skenario spasi pada kondisi MSL.

Nilai $K_{r}$ sebagai fungsi dari $H_{i} / g T^{2}$ pada kondisi HWL dengan $b=1 \mathrm{~cm}$ dan $b=$ $2 \mathrm{~cm}$ ditunjukkan pada grafik Figure 19 dan Figure 20. Grafik tersebut menunjukkan bahwa semakin besar nilai $H_{i} / g T^{2}$ maka semakin besar pula nilai $K_{r}$ nya dan sebaliknya semakin kecil nilai $H_{i} / g T^{2}$ maka semakin pula nilai $K_{r}$ nya baik pada kedua skenario spasi pada kondisi HWL.

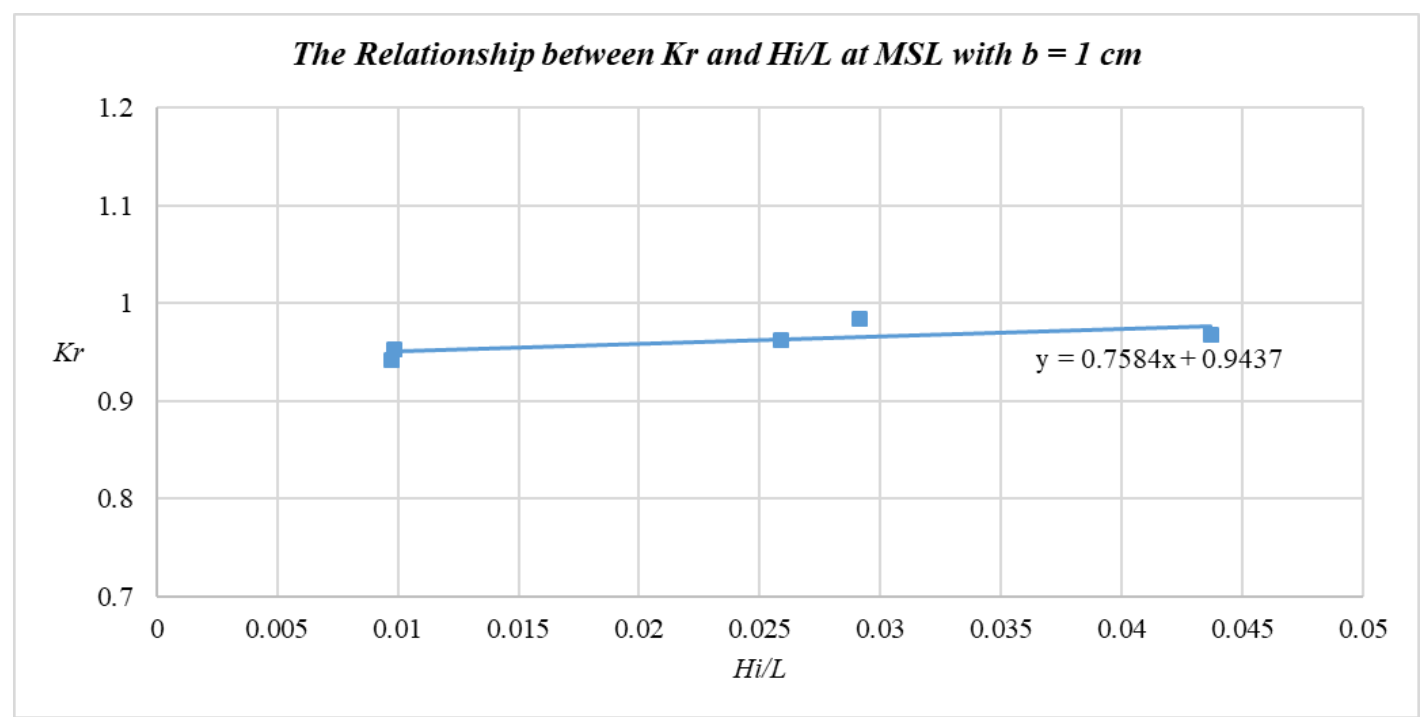

Figure 13. $K_{r}$ vs $H_{i} / L$ for MSL conditions with spaces $1 \mathrm{~cm}$.

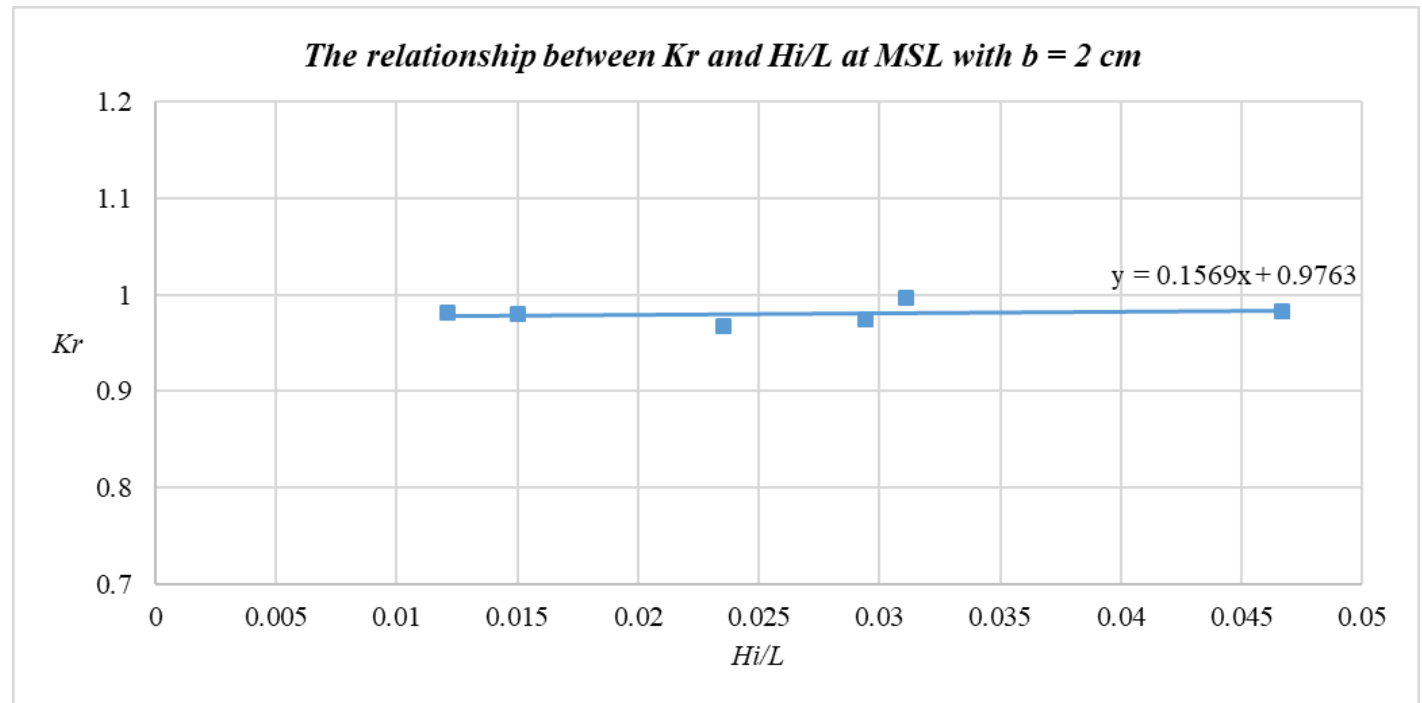

Figure 14. $K_{r}$ vs $H_{i} / L$ for MSL conditions with spaces $2 \mathrm{~cm}$. 


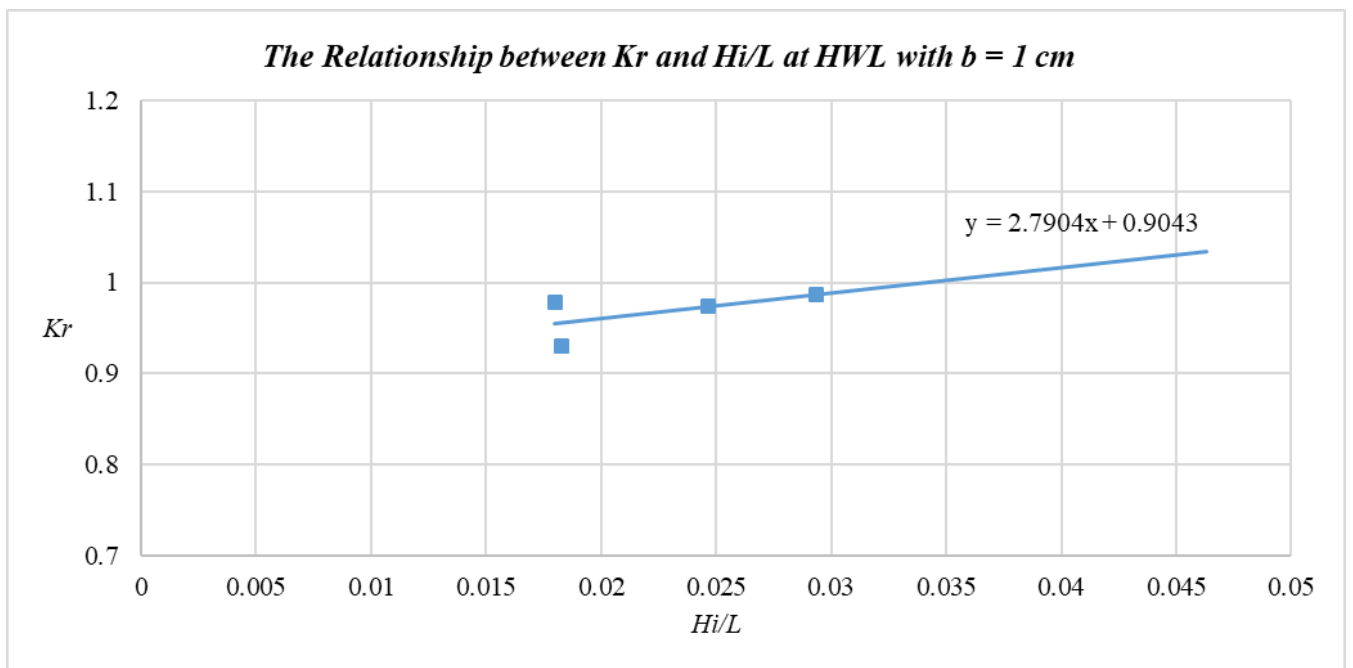

Figure 15. $K_{r}$ vs $H_{i} / L$ for $H W L$ conditions with spaces $1 \mathrm{~cm}$.

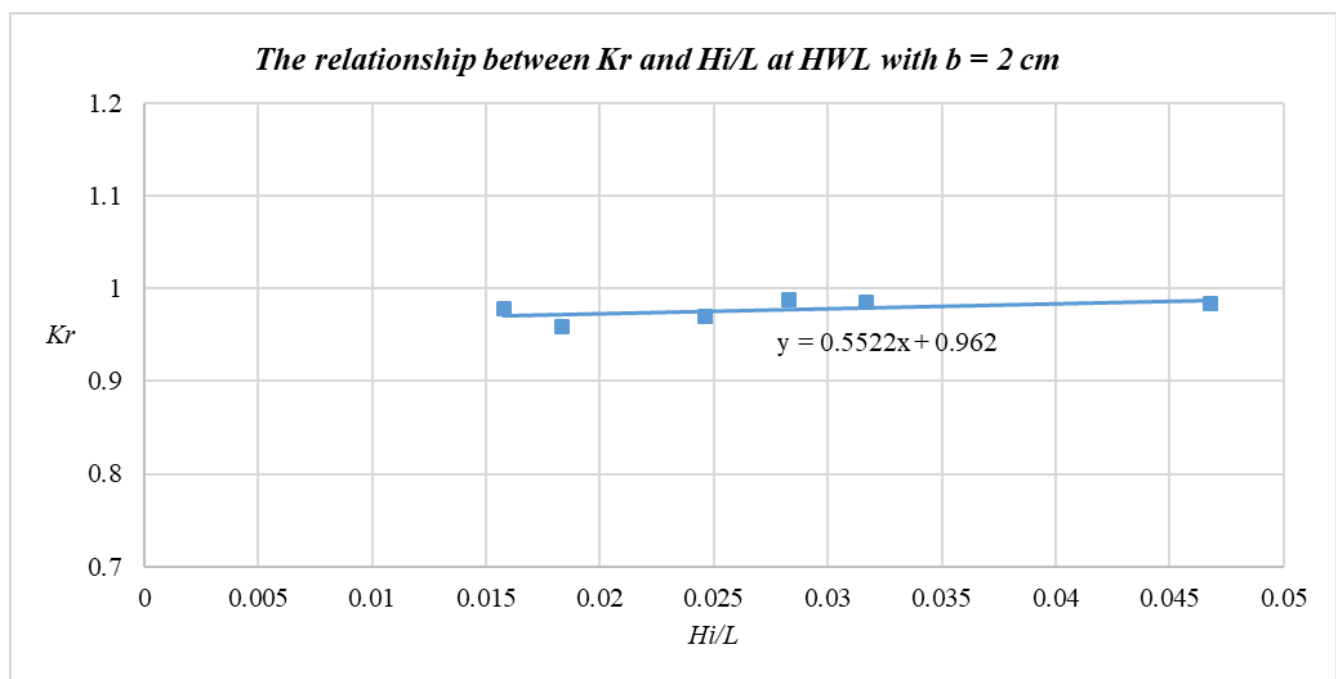

Figure 16. $K_{r}$ vs $H_{i} / L$ for $H W L$ conditions with spaces $2 \mathrm{~cm}$.

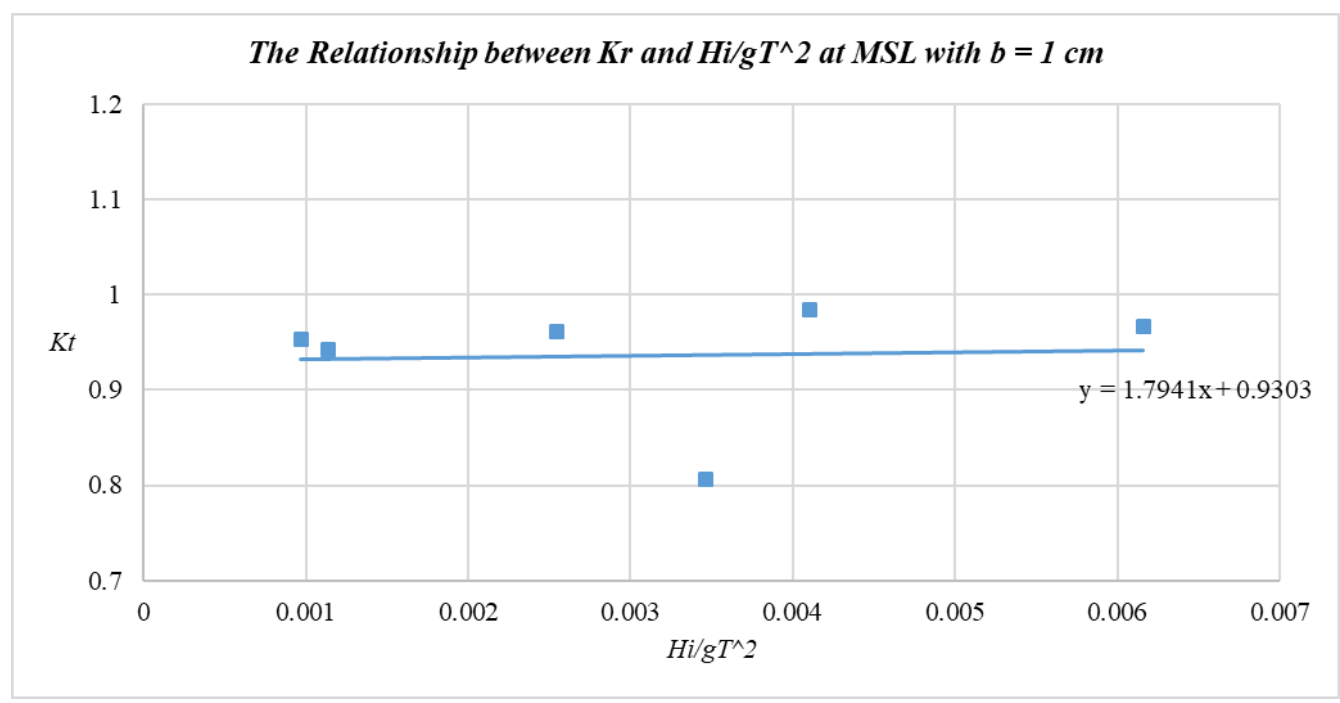

Figure 17. $K_{r}$ vs $H_{i} / g T^{2}$ for MSL conditions with spaces $1 \mathrm{~cm}$. 
Analisis Refleksi dan Transmisi Gelombang pada Pemecah Gelombang ...

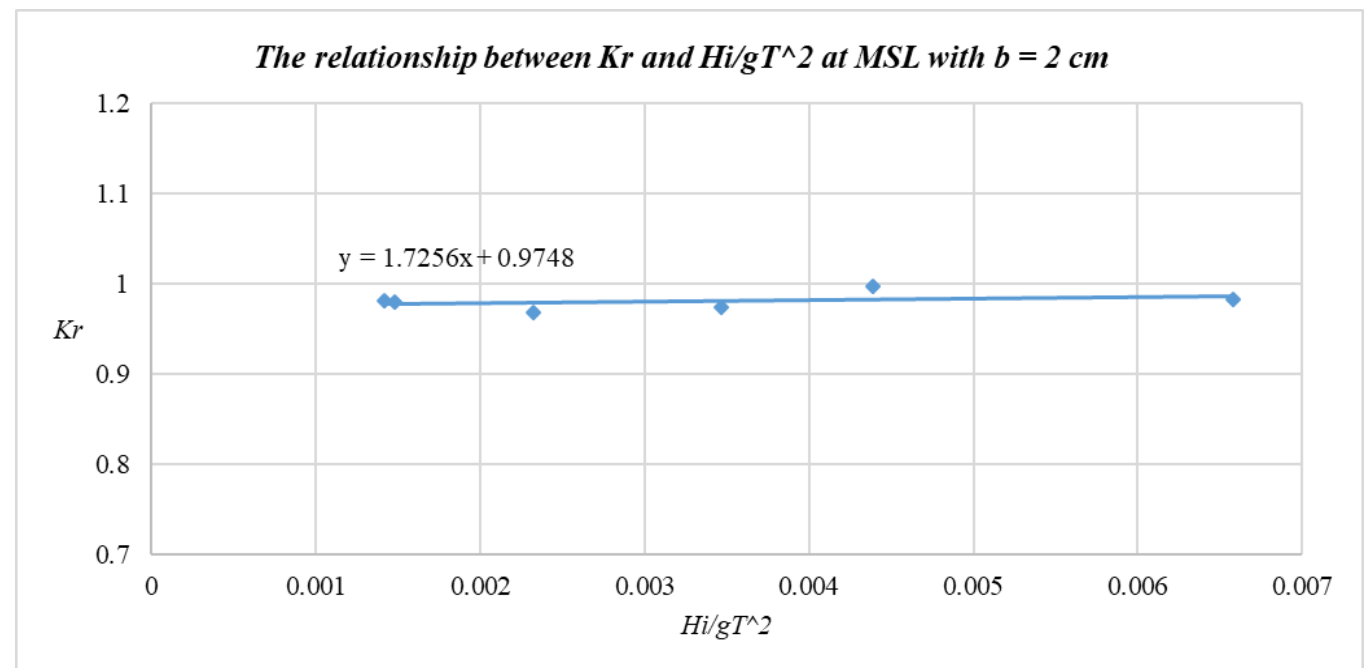

Figure 18. $K_{r}$ vs $H_{i} / g T^{2}$ for MSL conditions with spaces $2 \mathrm{~cm}$.

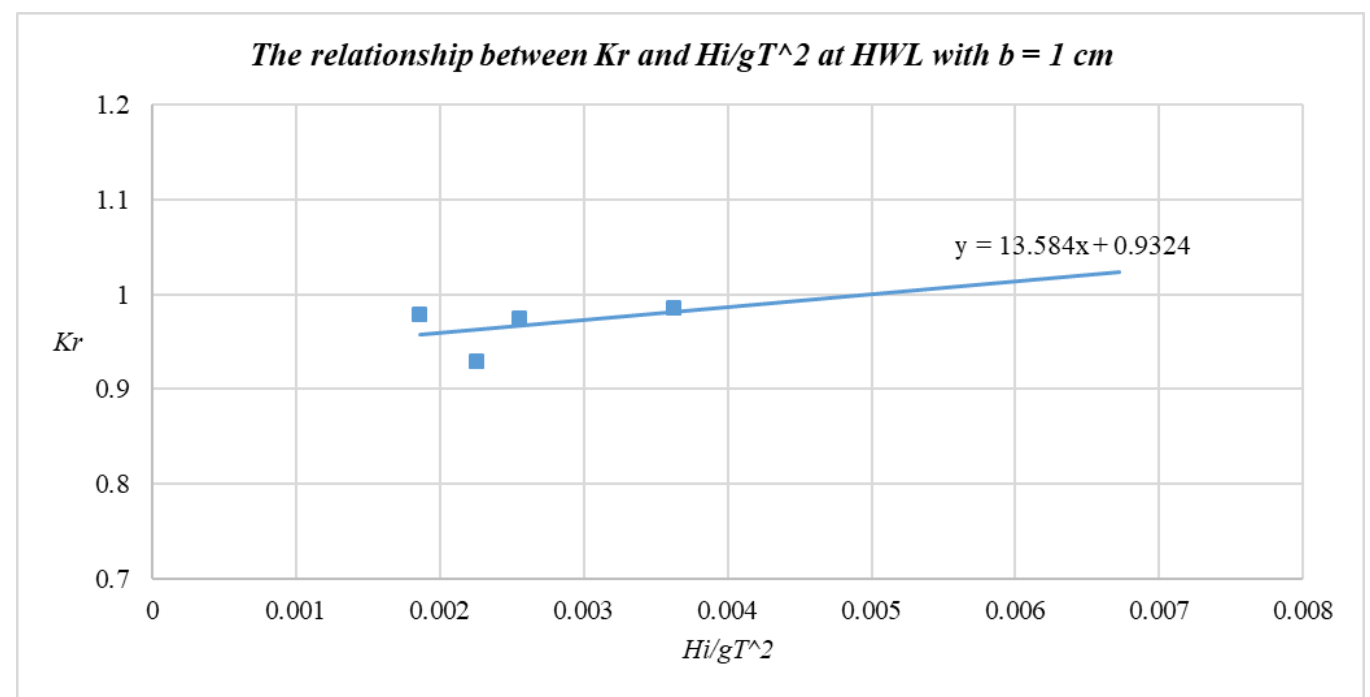

Figure 19. $K_{r}$ vs $H_{i} / g T^{2}$ for $H W L$ conditions with spaces $1 \mathrm{~cm}$.

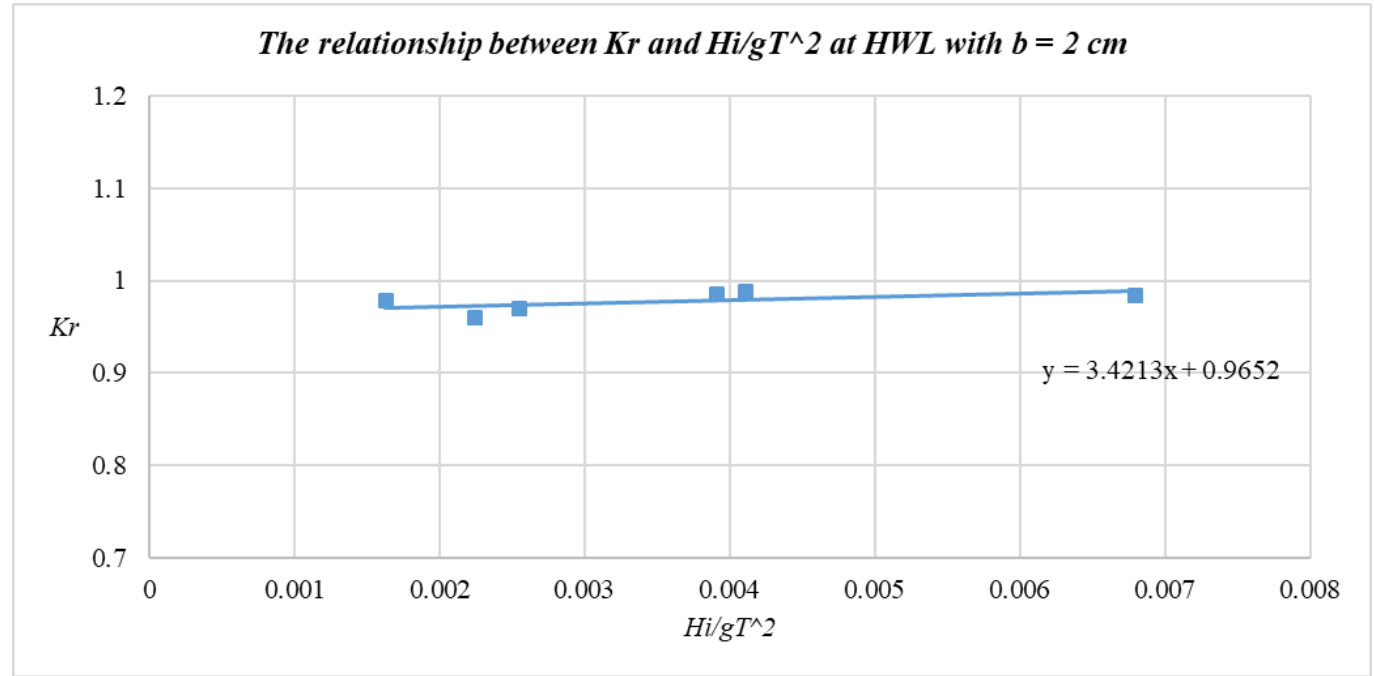

Figure 20. $K_{r}$ vs $H_{i} / g T^{2}$ for $H W L$ conditions with spaces $2 \mathrm{~cm}$. 


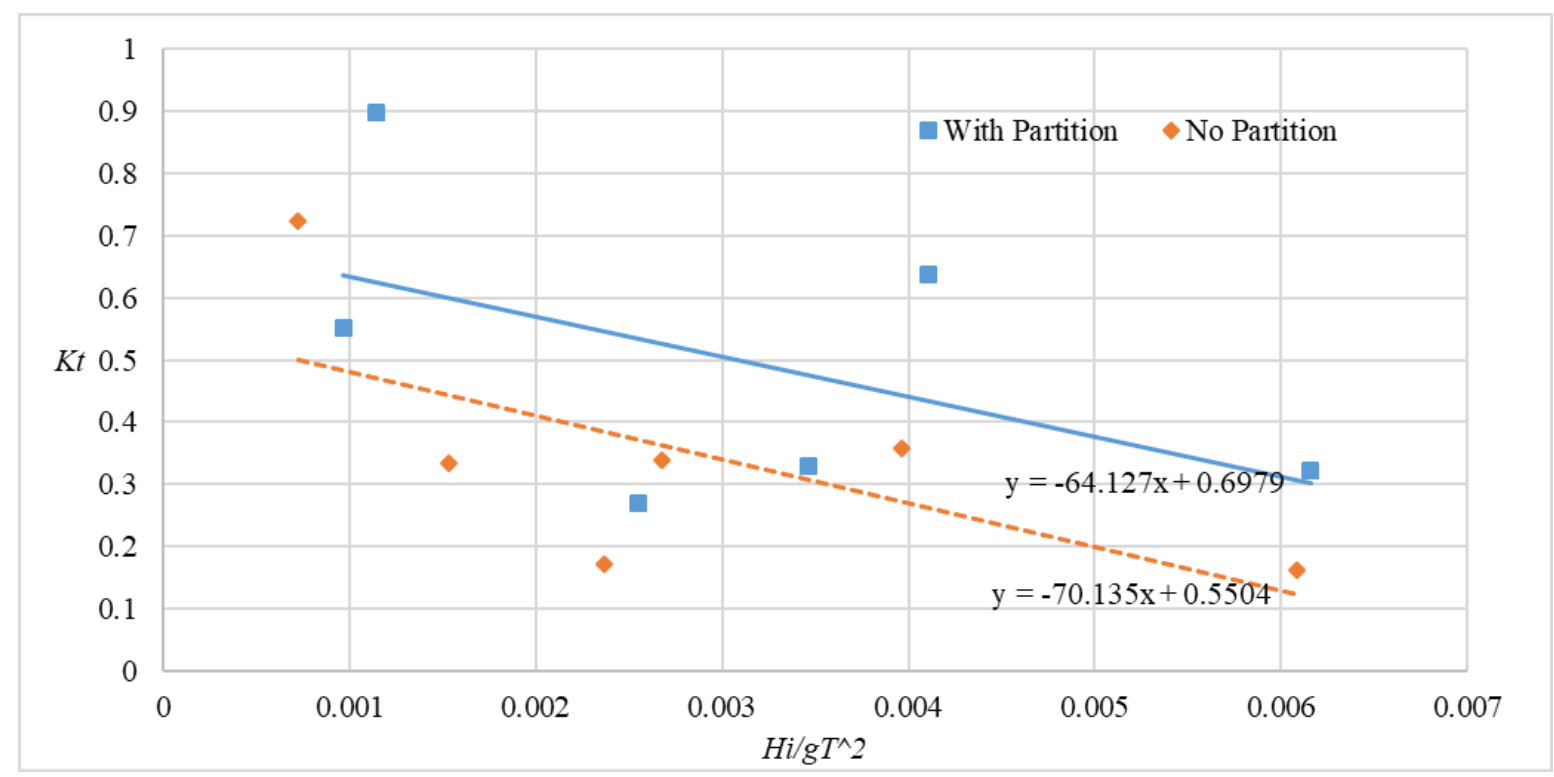

Figure 21. Effect of partition on the value of the transmission coefficient.

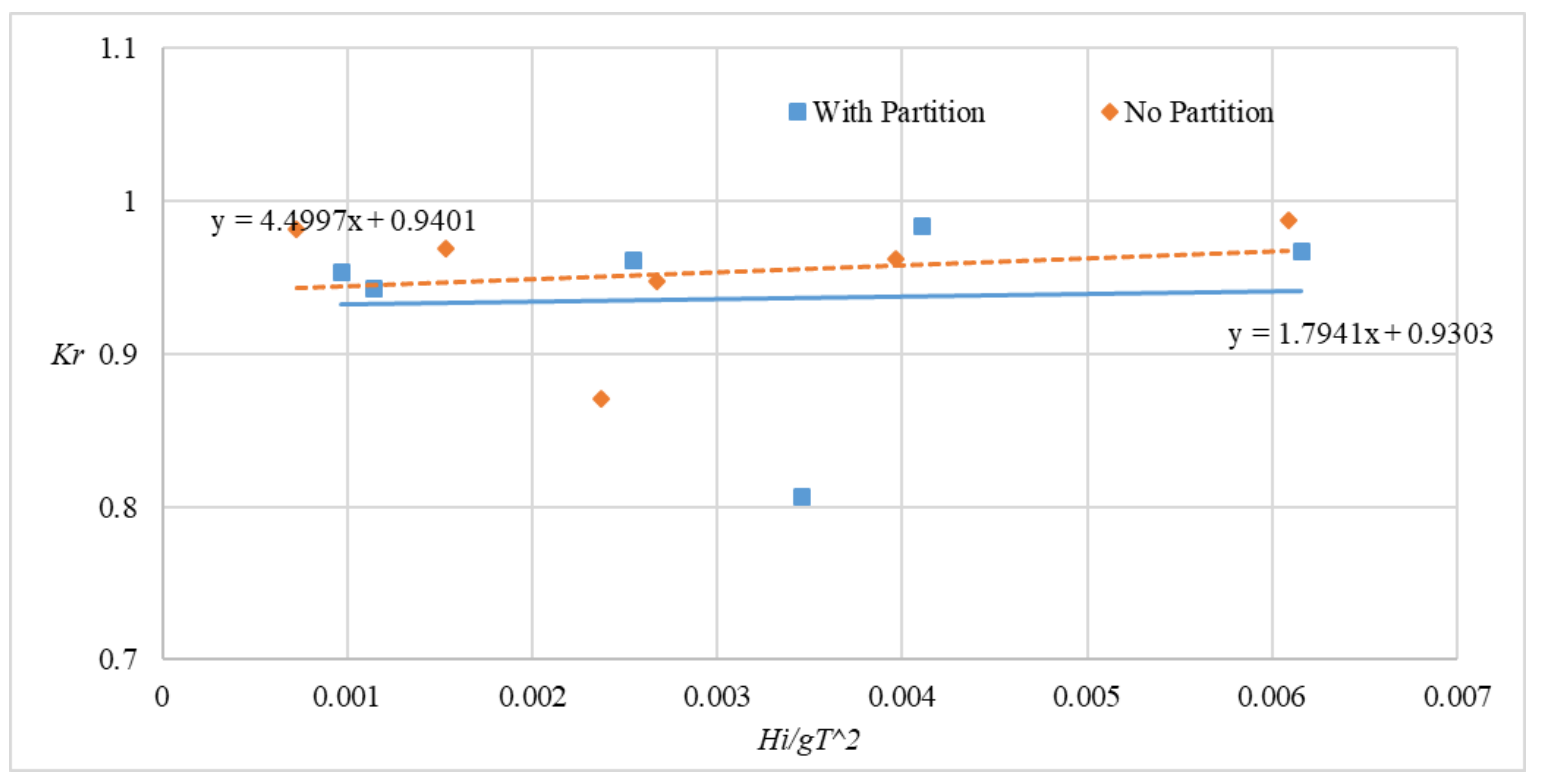

Figure 22. Effect of partition on the value of the reflection coefficient.

Table 2. The Relationship $K_{t}$ and $K_{r}$ with nondimensional variable and its correlation.

\begin{tabular}{ccccccc}
\hline $\begin{array}{c}\text { Water } \\
\text { Level }\end{array}$ & \multirow{2}{*}{ Space } & $\begin{array}{c}\text { Variable } \\
(x)\end{array}$ & $K_{t}$ & $K_{r}$ & $\begin{array}{c}\text { Correlation } \\
K_{t}\end{array}$ & $\begin{array}{c}\text { Correlation } \\
K_{r}\end{array}$ \\
\hline MSL & $1 \mathrm{~cm}$ & $H_{i} / L$ & $-12.465 \mathrm{x}+0.8086$ & $0.7584 \mathrm{x}+0.9437$ & -0.67 & -0.034 \\
& & $H_{i} / g T^{2}$ & $-64.127 \mathrm{x}+0.6979$ & $1.7941 \mathrm{x}+0.9303$ & -0.52 & 0.054 \\
& \multirow{2}{*}{$\mathrm{cm}$} & $H_{i} / L$ & $-2.4764 \mathrm{x}+0.5405$ & $0.1569 \mathrm{x}+0.9763$ & -0.27 & 0.20 \\
& & $H_{i} / g T^{2}$ & $-9.6254 \mathrm{x}+0.5034$ & $1.7256 \mathrm{x}+0.9748$ & -0.18 & 0.36 \\
HWL & \multirow{2}{*}{$\mathrm{cm}$} & $H_{i} / L$ & $-0.9104 \mathrm{x}+0.6739$ & $2.7904 \mathrm{x}+0.9043$ & -0.05 & 0.6 \\
& & $H_{i} / g T^{2}$ & $-4.2683 \mathrm{x}+0.6639$ & $13.584 \mathrm{x}+0.9324$ & -0.04 & 0.41 \\
& $2 \mathrm{~cm}$ & $H_{i} / L$ & $-2.7115 \mathrm{x}+0.8613$ & $0.5522 \mathrm{x}+0.962$ & -0.19 & 0.56 \\
& & $H_{i} / g T^{2}$ & $-14.493 \mathrm{x}+0.8369$ & $3.4213 \mathrm{x}+0.9652$ & -0.17 & 0.58 \\
\hline
\end{tabular}


Berdasarkan hasil pengujian model fisik 2D menggunakan pemecah gelombang tiang pancang, $K_{r}$ memiliki hubungan yang berbanding lurus terhadap variabel $H_{i} / L$ dan $H_{i} / g T^{2}$ yang berarti dengan nilai $K_{r}$ bertambah seiring dengan bertambahnya nilai dari kedua variable tersebut. Hasil tersebut sesuai dengan penelitian yang telah dilakukan oleh Anas (2014) bahwa nilai $K_{r}$ bertambah seiring dengan bertambahnya nilai $H_{i} / L$.

Jika dibandingkan antara model dengan kondisi MSL dan HWL, dapat dilihat bahwa nilai $K_{r}$ relatif lebih rendah pada saat kondisi HWL dan lebih besar pada kondisi MSL. Hasil ini sesuai dengan penelitian Herbich \& Douglas (1988) yang menyatakan bahwa semakin dalam perairan nilai $K_{r}$ semakin kecil. Hasil resume regresi linier dari setiap percobaan dapat disajikan pada Table 2.

\section{KESIMPULAN}

Berdasarkan hasil percobaan yang dilakukan, diperoleh kesimpulan, diantaranya adalah: (1) Figure 5 - Figure 22 menunjukkan bahwa apabila dibandingkan antara model dengan kondisi MSL dan HWL, dapat dilihat bahwa nilai $K_{t}$ lebih rendah pada saat kondisi MSL nilai $K_{r}$ lebih tinggi pada saat kondisi MSL. Hal ini menunjukkan bahwa Pemecah Gelombang Bambu Bulat Bersekat ini lebih efektif pada muka air rendah dari pada muka air tinggi. (2) Semakin besar spasi yang diberikan antar tiang, maka semakin besar energi gelombang yang diteruskan. (3) Nilai $K_{t}$ memiliki hubungan berbanding terbalik dengan kemiringan gelombang $\left(H_{i} / L\right)$ dan kecuraman gelombang $\left(H_{i} / g T^{2}\right)$. (4) Nilai $K_{r}$ memiliki hubungan berbanding lurus dengan kemiringan gelombang $\left(H_{i} / L\right)$ dan kecuraman gelombang $\left(H_{i} / g T^{2}\right)$. (5) Penggunaan pemecah gelombang tiang pancang akan lebih efektif terjadi pada lokasi perairan dengan kecuraman gelombang dan kemiringan yang lebih besar (dikategorikan gelombang pendek) dan dengan pemakaian spasi tiang pancang yang lebih rapat. (6) Penambahan sekat juga memberikan pengaruh terhadap nilai $K_{t}$ dan $K_{r}$ yaitu nilai $K_{t}$ yang lebih rendah dan nilai $K_{r}$ yang lebih besar. (7) Hasil pengujian fisik 2D menunjukkan hubungan $K_{t}$ dan $K_{t}$ dengan variabel nondimensional yang korelasinya telah disajikan pada Table 2.

\section{UCAPAN TERIMA KASIH}

Kami mengucapkan terima kasih kepada pengelola Balai Hidrolika dan Geoteknik Keairan Kementrian PUPR Singaraja-Bali atas bantuan dan kerjasamanya untuk pelaksanaan percobaan model fisik ini dan terimakasih juga kepada Program P3MI ITB serta program Hibah Penelitian ITERA-skema Riset Kolaborasi atas bantuan pendanaan penelitian ini.

\section{DAFTAR PUSTAKA}

Ajiwibowo, H. 2011. 2-D physical modeling to measure the effectiveness of perforated skirt breakwater for shortperiod waves. ITB J. Eng. Sci., 42(1): 57-78.

http://doi.org/10.5614\%2Fitbj.eng.sc i. 2011.43 .1 .5

Herbich, J.B. \& B. Douglas. 1988. Wave transmission through a double-row pile breakwater. Coastal Engineering Proceedings. 2229-2241 pp. https://doi.org/10.9753/icce.v21.165

Koftis, T., P. Prinos, \& M. Aftias. 2012. Experimental study of a multiple row pile breakwater. Researchgate, $1-9$.

https://www.researchgate.net/publica tion $/ 257251761$

Putra, A.O., H.D. Armono, \& Sujantoko. 2013. Pengaruh elevasi muka air laut pada koefisien transmisi dan refleksi composite breakwater. J. Teknik Pomits, 2(1): 2301-9271. http://doi.org/10.12962/j23373539.v 2i1.3106

Scarlatos, P. 2011. Effects of permeable breakwater on shallow wave 
propagation. Oceans '86, 18(1): 392397.

https://doi.org/10.1109/OCEANS.19 86.1160434

Somervell, L.T., S. Thampi, \& A. Shashikala. 2014. Wave reflection from corrugated perforated beach and vertical upright breakwater. International $J$. of Engineering Research and Technology, 3(12): 2629. https://www.ijert.org/wavereflection-from-corrugatedperforated-beach-and-verticalupright-breakwater

Sulaiman, D.M. 2017. Proposal kegiatan model pemecah gelombang tiang pancang Bali: Balai Pantai. Unpublished.

Sulaiman, D.M. \& A.A. Larasari. 2017. Rehabilitasi pantai dengan pemecah gelombang tiang pancang dari bambu bulat bersekat. Prosiding Simposium II-UNIID 2017. 443-449 pp.

http://conference.unsri.ac.id/index.ph p/uniid/article/view/637/249
Thaha, M., S. Pongmanda, \& M. Reza. 2015. Studi pengaruh kedalaman puncak pemecah gelombang tenggelam tipe blok beton berpori terhadap transmisi gelombang. $J$. Teknik Sipil UNHAS.

http://repository.unhas.ac.id/handle/1 23456789/13000

Umar. 2011. Kajian pengaruh gelombang terhadap kerusakan pantai matang danau Kabupaten Sambas. J. Teknik Sipil UNTAN, 11(1): 93-102. http://doi.org/10.26418/jtsft.v11i1.10 68

Wurjanto, A., H. Ajiwibowo, \& R. Zamzami. 2010. Pemodelan fisik 2D untuk mengukur tingkat efektivitas perforated skirt breakwater pada kategori gelombang panjang. $J$. Teknik Sipil, 17(03): 211-226. http://doi.org/10.5614\%2Fjts.2010.1 7.3.7

Received : 30 September 2019

Reviewed : 5 July 2020

Accepted : 11 December 2020 
